\section{Perceptions, health care seeking behaviour and implementation of a tuberculosis control programme in Lambaréné, Gabon}

\author{
A. L. Cremers, ${ }^{1,2,3}$ S. Janssen, ${ }^{1,2}$ M. A. M. Huson, ${ }^{1,2}$ G. Bikene, ${ }^{2}$ S. Bélard, ${ }^{1,2}$ R. P. M. Gerrets, ${ }^{3}$ \\ M. P. Grobusch ${ }^{1,2}$
}

http://dx.doi.org/10.5588/pha.13.0038

Setting: Lambaréné, Gabon.

Objectives: To describe patient perceptions of tuberculosis (TB) and to determine factors that influence health care seeking behaviour to gain insight into the management of multidrug-resistant TB.

Design: Participant observation, in-depth semi-structured interviews and focus group discussions were conducted with 30 TB patients, 36 relatives, 11 health care providers and 18 traditional/spiritual healers. Recruitment of patients was linked to the PanEpi study and took place at the Albert Schweitzer Hospital, the General Hospital and the TB-HIV (human immunodeficiency virus) clinic.

Results: Patients generally described TB as a natural and/ or magical disease. The majority of the patients combined treatment at the hospital with (herbal) self-treatment and traditional/spiritual healing. Despite the free availability of anti-tuberculosis treatment in principle, patient adherence was problematic, hindering effective TB control. Most patients delayed or defaulted from treatment due to financial constraints, stigmatisation, ignorance about treatment, change of health care service or use of non-prescribed antibiotics. The situation was occasionally complicated by drug stockouts.

Conclusion: There is an urgent need to bridge the gap between patients and the hospital by avoiding drug shortages, intensifying culturally sensitive TB health education, embedding TB care into the cultural context and enhancing cooperation between hospitals, patients, traditional healers and communities.

W ith an estimated worldwide incidence of 9.4 million cases in 2009, tuberculosis (TB) remains a major public health problem, and the epidemic is increasing despite efforts to contain it. ${ }^{1}$ Eighty per cent of all TB patients live in sub-Saharan Africa, ${ }^{2}$ where the disease is putting enormous pressure on many health care systems.

In Gabon, the estimated incidence of TB is 450 per 100000 population; $46 \%$ of all TB patients are coinfected with the human immunodeficiency virus (HIV) and 10\% have multidrug-resistant TB (MDRTB), ${ }^{3}$ posing a severe global public health threat. The Gabonese National TB Programme (NTP) is responsible for (passive) case detection and provides antituberculosis treatment without cost; however, drug stockouts occur repeatedly, there is no countrywide infrastructure for sputum culture and drug susceptibility testing, and the World Health Organization (WHO) promoted TB control strategy is not implemented. As in other settings, ${ }^{4-7}$ adherence problems contribute to a low (34\%) treatment completion rate, with $45 \%$ of patients defaulting from treatment. 8

In general, cultural, economic and social considerations play a significant role in treatment adherence. Traditional and spiritual healing services, which are commonly used by Gabonese TB patients, constitute an important alternative to hospital services. Economic factors are significant, as $\mathrm{TB}$, classified as a disease of the poor and facilitated by inadequate nutrition or overcrowded living conditions, places a financial burden on most patients. ${ }^{6,7,9}$ Gabonese patients often face financial problems regarding transport or in accessing treatment during the frequent temporary national drug stockouts. Social constraints exist, as TB often generates stigma, a discrediting social label.7,10,11

In Gabon, little research has been conducted so far on TB. $8,12,13$ No medical socio-anthropological TB research has been published, and previously published studies from other areas have proven important for health care improvement. ${ }^{4-7,11}$ Considering the major issues surrounding TB in Gabon, such research is highly relevant as it provides knowledge about the health care seeking behaviour of patients, which may guide the development of interventions for the prevention of $\mathrm{TB}$ drug resistance.

\section{METHODS}

The study population consisted of patients aged $>18$ years and diagnosed with TB recruited into an ongoing TB epidemiology study in Lambaréné, Gabon. Families of patients, health care providers, traditional healers registered with the Gabonese National Traditional Healer Association and spiritual healers (Catholic, Protestant, Pentecostal, Celeste and Reveil churches) were approached.

In 2012, a 4-month case study was conducted using a mixed-methods approach that consisted of document analysis, participant observation, in-depth semistructured interviews and focus group discussions.

Participant observation was conducted at the Albert Schweitzer Hospital, the general regional hospital, the governmental ambulatory health care centre for HIV and TB, patient homes, traditional healing sessions, spiritual healing sessions and the Institut de Pharmacopée et de Médecine Traditionnelles (governmental institute for herbal treatment). Respondents were interviewed repeatedly using a questionnaire on
AFFILIATIONS

1 Center of Tropical and Travel Medicine, Department of Infectious

Diseases, Division of Internal Medicine, Academic Medical Center, University of Amsterdam, Amsterdam, The Netherlands

2 Centre de Recherches Médicales de Lambaréné, Lambaréné, Gabon

3 Faculty of Social and Behavioural Science, Department of Sociology and Anthropology, University of Amsterdam,

Amsterdam, The

Netherlands

CORRESPONDENCE M P Grobusch Center of Tropical and Travel Medicine

Department of Infectious Diseases

Division of Internal Medicine Academic Medical Center University of Amsterdam Amsterdam, The Netherlands Tel: (+31) 205662097 Fax: (+31) 206972286 e-mail: m.p.grobusch@ amc.uva.nl

ACKNOWLEDGMENTS The authors thank the staff of the Albert Schweitzer Hospital, Lambaréné, and le Centre de Recherches Médicales de Lambaréné, Lambaréné, participating patients, health care providers, and traditional and spiritual healers. Their thanks also go to the directors of the Programme National de Lutte contre la Tuberculose, the World Health Organization, and the Institut de Pharmacopée et de Médecine Traditionnelles, Libreville, Gabon. Conflict of interest: none declared.

KEY WORDS public health; adherence; stigma; tuberculosis

Received 27 May 2013 Accepted 10 October 2013

PHA 2013; 3(4): 328-332 C 2013 The Union 
socio-demographics, treatment, perceptions about TB, health care services and stigma. The latter three topics were also discussed during two focus group discussions with TB patients, acquaintances and health care providers.

Ethical approval was obtained from the institutional review board of the Centre de Recherches Médicales de Lambaréné (CEI-MRU number: 011/2012). Informed consent was provided by respondents before recruitment, interviews and observation.

\section{RESULTS}

Thirty TB patients, 36 relatives, 11 health care providers and 18 traditional/spiritual healers were included. Patients attended the hospital to see a doctor and for sputum analysis after a period of coughing and/or being ill (range 2 weeks-2 years), and were generally unaware of having TB $(27 / 30,90 \%)$. At arrival, the majority of the patients $(18 / 30,60 \%)$ had already developed signs and symptoms that had profoundly compromised their daily living activities. Almost half of the patients (14/30, 47\%) were so ill that they were convinced they would not survive. Four patients (13\%) died due to TB during the 4-month study period. Eight patients (27\%) defaulted from the treatment provided by the hospital.

\section{Perceptions regarding tuberculosis}

An examination of local terms for TB revealed five aetiological causes of the disease: 1) vampires or fusils nocturnes (night rifle), i.e., evil spirits launched with the help of sorcery, 2) poisons, 3) demons, Gabonese nature spirits, 4) germs, and 5) God. TB caused by the first three agents was considered magical TB (disease of the
Blacks), in contrast to the latter two agents, which caused natural TB (disease of the Whites). Sometimes TB was considered both magical and natural, referring to at least two of the aetiological causes. Twenty-four of the patients (80\%) believed evil spirits could make you ill. The remaining six patients and all of the spiritual healers acknowledged the existence of spirits, but did not believe in them, as this could aggravate illness.

Respondents described different ways of diagnosing the cause of TB. Although hospital tests were seen as the best method, only seven patients (23\%) initially made use of these. Positive test results meant that the patient had natural $\mathrm{TB}$, while negative results suggested magical origins. However, diagnostic difficulties (sputum-negative or extra-pulmonary $\mathrm{TB}$ ) or inadequate diagnostics (e.g., only taking a blood sample) could at times be interpreted as magical TB (interviews with health care providers, focus group discussions). Moreover, if TB was diagnosed magically by spiritual or traditional healers, the patients did not attend the hospital, believing that the treatment intended for Whites would not be effective.

\section{Anti-tuberculosis treatment}

Twenty-two patients (73\%) agreed that magical TB could only be treated by a traditional/spiritual healer, in contrast to natural TB, which could also be cured in the hospital. Six patients (20\%) believed that TB did not have magical causes and thought that it could only be cured in the hospital.

The majority of the patients had turned to various forms of health care such as (medicinal) plants, pharmacy, fokoro (antibiotics without prescription), the hospital, traditional healing and

TABLE 1 Health care services used by tuberculosis patients in Lamberéné, Gabon

\begin{tabular}{|c|c|c|c|c|}
\hline$\#$ & First choice & Second choice & Third choice & Fourth choice \\
\hline 1 & Plants & Traditional healer & Hospital & \\
\hline 2 & Plants & Hospital & Traditional healer & \\
\hline 3 & Plants & Exorcism and prayer & Fokoro* & Hospital \\
\hline 4 & Plants & Exorcism and prayer & Fokoro & Hospital \\
\hline 5 & Plants & Traditional healer & Hospital and prayer & \\
\hline 6 & Plants & Hospital & & \\
\hline 7 & Plants & Exorcism and prayer & Hospital & \\
\hline 8 & Plants & Hospital & & \\
\hline 9 & Plants & Hospital and prayer & & \\
\hline 10 & Plants & Pharmacy & 4 traditional healers & Hospital \\
\hline 11 & Plants & Pharmacy & Hospital and prayer & Traditional healer ${ }^{\dagger}$ \\
\hline 12 & Plants & Traditional healer & Hospital & \\
\hline 13 & Plants and traditional healer & Hospital & Traditional healer & \\
\hline 14 & Plants and fokoro & Hospital and prayer & & \\
\hline 15 & Plants and pharmacy & Hospital and prayer & Exorcism & \\
\hline 16 & Hospital & & & \\
\hline 17 & Hospital & & & \\
\hline 18 & Hospital and prayer & & & \\
\hline 19 & Hospital and prayer & & & \\
\hline 20 & Hospital & Traditional healer & & \\
\hline 21 & Hospital, exorcism and prayer & & & \\
\hline 22 & Hospital and plants & Traditional healer $\ddagger$ & & \\
\hline 23 & Pharmacy & Plants & Hospital & \\
\hline 24 & Pharmacy & Hospital & & \\
\hline 25 & Pharmacy & Traditional healer & Hospital & \\
\hline 26 & Pharmacy & Hospital and traditional healer & & \\
\hline 27 & Pharmacy & Hospital and prayer & Traditional healer ${ }^{\dagger}$ & \\
\hline 28 & Pharmacy & Hospital & & \\
\hline 29 & Pharmacy and prayer & Hospital & & \\
\hline 30 & Fokoro & Hospital and prayer & & \\
\hline
\end{tabular}

*Antibiotics without prescription.

†Option for the future, in case hospital treatment did not work.

¥ Patient died before going to traditional healer. 
spiritual healing (prayer or exorcism; Table 1). Twenty-two patients (73\%) had combined Western and spiritual/traditional health care, mostly successively (20/30, 67\%), when perceptions regarding TB changed or the various healing services were viewed as effective yet too powerful to be used simultaneously.

Fifteen patients (50\%) initially used (medicinal) plants. All respondents said that in almost every Gabonese family someone had traditional knowledge about herbal treatments, making this healing method common and easily accessible.

When I fell ill, my mother started of course with the trick of the village. She used wood, leaves, medication to get me back, to get me better. (Patient interview)

One third of the patients $(9 / 30,30 \%)$ first went to the pharmacy or bought fokoro, believing their TB to be ordinary fever or cough. A third group began with a hospital visit (7/30, 23\%).

For many of the patients, the hospital was not the first choice of health care, and it was even considered problematic or unacceptable by some. Long treatment and correct use of TB medication were difficult since "many Gabonese patients have "another concept of time" being less punctual or future-oriented' (interviews with health care providers, participant observation). Moreover, many Gabonese people did not believe that diseases could be chronic or prolonged; rather, diseases were considered as instantly curable. Some patients felt that the Whites and their hospitals were a threat to traditional health care practices (interviews with health care providers, 3 patients, focus group discussions, participant observation).

Almost a quarter of the respondents $(7 / 30,23 \%)$ believed in the importance of traditional health care, which is deeply anchored in local religion. Use of traditional health care requires an initiation ritual, a ceremony to become part of the ethnic group, as illustrated by the following quote:

I was initiated. That is obligatory here in the village. You have to secure yourself against sorcery and vampires. I was 12 and wanted my initiation so badly. All my friends had done it already. (Patient interview)

Informants explained that without initiation there was a risk of becoming marginalised:

Because you are not protected against evil spirits and more importantly, you are not part of the group. (Patient interview)

Almost half of the patients made use of spiritual healing through prayer $(13 / 30,43 \%)$ and exorcism $(4 / 30,13 \%)$. According to these patients and spiritual healers, this gave strong psychological support. Two patients and two spiritual healers described how certain spiritual healers prevented patients from going to the hospital as they claimed this was unnecessary.

\section{Socio-economic factors}

Most patients (28/30, 93\%) had low socio-economic status, as determined from their housing, education and narratives (interviews, participant observation). They lived in wooden houses with few windows and no running water. Patients lived with on average six other household members (range 0-30). Nineteen patients (63\%) were financially responsible for their family; their disease therefore placed a significant economic burden on the household. Two patients $(7 \%)$ had postponed a hospital visit because they were unable to leave work for financial reasons or children, or pay for transport.

In principle, the NTP covered anti-tuberculosis medications, but patients occasionally had to buy their drugs from local pharmacies (maximum €70-110 per month) due to drug shortages, resulting in three patients (9\%) defaulting from treatment. Traditional
TABLE 2 Stigma and TB patients in Lamberéné, Gabon $(N=30)$

\begin{tabular}{lc}
\hline Experience with stigma & $n(\%)$ \\
\hline Not problematic & $10(33)$ \\
Not (or less) problematic, as TB is curable & $15(50)$ \\
Problematic & $20(67)$ \\
Difficulties at social level & $17(57)$ \\
Trouble at work & $2(7)$ \\
Inform only some people about their TB & $8(27)$ \\
Conceal/deny they had TB & $2(7)$ \\
Knowing someone who conceals/denies having TB & $3(10)$ \\
Double stigma: TB and HIV & $4(13)$ \\
No TB stigma, only HIV stigma & $2(7)$ \\
\hline
\end{tabular}

$\mathrm{TB}=$ tuberculosis; HIV = human immunodeficiency virus.

healers charged around $€ 200$ for treating TB, which was sometimes cheaper and more accessible, being located in the villages.

Generally, the educational level of the patients was low; they (had) attended primary school (67\%), secondary school (37\%) or occupational training courses $(9 \%)$. None of the patients nor their families knew in advance that anti-tuberculosis treatment was provided free of charge. However, health care providers, two spiritual healers and three traditional healers were aware of this. Two patients $(7 \%)$ had defaulted from treatment because they felt cured, not realising that they could relapse. TB was only briefly discussed in primary school. One non-governmental organisation for TB was located in Libreville, but no campaigns had been conducted in Lambaréné.

The majority of the patients felt stigmatised, describing their disease as socially problematic (20/30, 67\%). They understood people's fear of becoming infected and therefore occasionally concealed from others the fact that they had TB (Table 2). Two of the study patients $(7 \%)$ denied having $\mathrm{TB}$, and three patients $(9 \%)$ had an acquaintance who denied having TB. Going to a traditional healer guaranteed greater privacy, as they were located nearby and visits could be arranged quickly. As a consequence, the patients felt less stigmatised (focus group discussions, participant observation, patient and health care provider interviews).

\section{DISCUSSION}

In Gabon, TB remains a major issue despite the free access to antituberculosis drugs. Based on an analysis of TB perceptions and the health care seeking behaviour of TB patients, this case study demonstrates how cultural, social and economic factors influencing patient adherence prevent successful implementation of the TB control programme.

Illness perceptions are an important focus of medical research, as these generally affect health care seeking behaviour. ${ }^{14-19}$ In Gabon, the respondents explained TB in a biomedical (natural) and/ or traditional/religious (magical) way. This dichotomy is often described in African settings:11,16,20,21 having natural TB explained how a patient got infected with TB bacteria, but did not explain why the person got ill. Having magical TB meant jealous people had performed sorcery on the patient. In contrast to a Tanzanian study on malaria, ${ }^{21}$ traditional explanations were used not only when medical knowledge met its limits, such as in the case of negative test results or treatment failure; inadequate diagnostics also occasionally evoked suspicions of magical TB, which called for traditional/spiritual healing. Moreover, when traditional/spiritual healers diagnosed magical $\mathrm{TB}$, patients were encouraged to avoid the hospital or to default from treatment as the treatment of Whites was considered ineffective. 
It thus becomes clear why patient and care giver perceptions of $\mathrm{TB}$ are an essential factor in health care seeking behaviour. There may have been selection bias in the study, as all patients were recruited from recognised health care services. Nevertheless, valuable insights were gained, as most respondents did not present first to the hospital, a finding that is in contrast to a Kenyan study. ${ }^{7}$ Data were gathered regarding patients' pluralistic health treatment, $4,11,19,22,23$ i.e., combining various formal and informal health care services, such as hospitals, pharmacies, traditional/ spiritual healers and herbal treatment.

Hospital delays and treatment default led in approximately half of the cases to such a poor state of health that the patients were convinced that they would not survive. This was related to poor financial situation or the patient's impression of being healthy, a finding supported by previous work on TB in Gabon. ${ }^{8}$ However, drug shortages, the availability of fokoro, use of alternative health care services and stigma were other important determinants.

As previous research suggests, the degree of stigma attached to TB was not as great as that attached to HIV; ${ }^{24}$ however, TB-HIV co-infected patients were often doubly stigmatised. Felt or feared stigma occasionally led to fear of disclosure and self-exclusion from health care services. ${ }^{25}$ One study described how the chronic nature of TB aggravated stigma. ${ }^{7}$ Interestingly, during focus group discussions and interviews, TB stigma was often denied because of the curable nature of the disease. In fact, it was said that many Gabonese people denied the concept of chronic or long-term diseases, and preferred traditional healers, who supposedly provided immediate cure.

Structural factors such as poverty, poor infrastructure or NTP drug shortages negatively impacted the patient's ability to adhere to treatment. The majority of the TB patients were of low socio-economic status and faced financial difficulties with transport or drugs. In Gabon, the distance to the health centre is the most important determinant of survival for malaria patients. ${ }^{20,26,27}$ Traditional healing was occasionally considered by patients to be cheaper and more convenient, in line with reports from other studies.6,7 However, traditional healing sessions were also often expensive. Furthermore, none of the patients knew that TB medication at the hospital was provided free of charge in principle.

TB is an under-addressed topic in Gabonese health education, and the early symptoms are initially believed to be ordinary cough, hence the preference for herbal treatment. People should be made more aware of TB symptoms and the danger of prolonged selftreatment. In addition, an understanding of anti-tuberculosis treatment is necessary to avoid the development of drug resistance. Furthermore, the consequences of fokoro use should be researched. In Gabon, where the prevalence of multidrug-resistant TB (MDR$\mathrm{TB}$ ) among $\mathrm{TB}$ cases is $10 \%,{ }^{3}$ and a second-line drug repository is lacking, ${ }^{13}$ this is highly urgent.

The usual theories on poverty and low level of education do not adequately explain the spread of TB, however. Important too, especially in rural areas, were deep-seated traditional beliefs and the fear of being marginalised if TB patients did not use traditional healing. Protection against witchcraft and magical diseases provided by a traditional healer was often mandatory. However, these social expectations and associated power structures have not been reported by previous socio-anthropological TB studies. 5,6,11,25 This finding highlights the need for culturally sensitive $\mathrm{TB}$ health education in which traditional/religious perceptions and practices are not neglected, but identified as part of the cultural context. Similarly, embedding the medical perspective in the socio-cultural context could advance communications between health care providers and patients. $6,7,25$

Interaction between hospitals and traditional/spiritual healers is advocated by the WHO. ${ }^{28}$ In the light of the fact that $30 \%$ of the TB patients presented to traditional healers, such calls for integration of traditional healers into national health systems should receive continued support. This collaboration is important to soften defensive patient attitudes to hospitals and encourage patient adherence.

Previous work has elaborated on the substantial influence of family and community members on health care seeking behaviour, resulting in shorter hospital delays. ${ }^{6}$ Their influence and possible cooperation should be further explored.

\section{CONCLUSION}

Attention should be given to the influence of structural, cultural and socio-economic factors on the health care seeking behaviour of TB patients, as this has a major impact on infection and the emergence of MDR-TB. In addition to structural improvements in hospital diagnostics, availability of drugs and reduction of transport costs, it is important to provide culturally sensitive TB education, embed medical perspectives in the cultural context and involve traditional healers and communities in bridging the gap between patients and care givers to improve TB control programmes.

\section{References}

1 World Health Organization. Multidrug- and extensively drug-resistant TB. Global report on surveillance and response. WHO/HTM/TB/2010.3.1. Geneva, Switzerland: WHO, 2010.

2 Lawn S D, Zumla A. Tuberculosis. Lancet 2011; 378: 57-72.

3 World Health Organization. Global tuberculosis report. WHO/HTM/TB/2012.6. Geneva, Switzerland: WHO, 2012: pp 105-128.

4 Hudelson P. Gender differentials in tuberculosis: the role of socio-economic and cultural factors. Tubercle Lung Dis 1996; 77: 391-400.

5 Azevedo M J, Prater G S, Hayes S C. Human immunodeficiency virus and tuberculosis coinfections in Kenya: environment, resources and culture. Int J Sociol Anthropol 2010; 2: 55-65.

6 Pronyk P M, Makhubele M B, Hargreaves J R, Tollman S M, Hausler H P. Assessing health seeking behaviour among tuberculosis patients in rural South Africa. Int J Tuberc Lung Dis 2001; 5: 619-627.

7 Liefooghe R, Baliddawa J B, Kipruto E M, Vermeire C, de Munynck A O. From their own perspective. A Kenyan community's perspective of tuberculosis. Trop Med Int Health 1997; 2: 809-821.

8 Mve M T, Bisvigou U, Barry N C D, Ondo C E, Nkoghe D. Les causes d'abandon et les motivations d'une reprise de traitement au centre antituberculeux de Libreville (Gabon). Cah Santé 2010; 20: 31-34. [French]

9 Schwartzman K, Menzies D. Tuberculosis: 11. Nosocomial disease. CMAJ 1999; 161: 1271-1277.

10 Goffman E. Notes on the management of spoiled identity. Englewood Cliffs, NJ, USA: Prentice-Hall, 1963: p 3.

11 Banerjee A, Harries A D, Nyirenda T, Salaniponi F M. Local perceptions of tuberculosis in a rural district in Malawi. Int J Tuberc Lung Dis 2000; 4: 1047-1051

12 Alloghe E E, Mve T M, Ramarojoana S, Iba Ba J, Nkoghe D. Epidemiologie de tuberculose infantile au centre antituberculeux de Libreville de 1997-2001. Med Trop 2006; 66: 469-471. [French]

13 Mounguengui D, Ondounda M, Mandji Lawson J M, et al. Tuberculose multirésistante à l'hôpital d'instruction des armées de Libreville (Gabon) à propos de 16 cas. Bull Soc Pathol Exotique 2012; 105: 1-4. [French]

14 Creyghton M. Communication between peasant and doctor in Tunisia. Soc Sci Med 1977; 11: 319-324.

15 Greenwood B. Cold or spirits? Choice and ambiguity in Morocco's pluralistic medical system. Soc Sci Med B 1981; 15: 219-235.

16 Janzen J M. Ngoma: discourses of healing in central and southern Africa. 1st ed. Berkeley and Los Angeles, CA, USA: University of California Press, 1992: xi.

17 Hoffer C. Islamitische genezers en hun patiënten: Gezondheidszorg, religie en zingeving. 2nd ed. Amsterdam, The Netherlands: Het Spinhuis, 1994: 166, 171. [Dutch]

18 Brown P. Naming and framing: the social construction of diagnosis and illness. J Health Soc Behav 1995; Spec No: 34-52. 
19 Hunt L, Mattingly C. Diverse rationalities and multiple realities in illness and healing. Med Anthropol Q 1998; 12: 267-272.

20 Gysels M, Pell C, Mathanga D P, et al. Community response to intermittent preventive treatment of malaria in infants (IPTi) delivered through the expanded programme of immunisation in five African settings. Mal J 2009; 8: 1670-1678.

21 Hausmann S, Ribera J M, Tanner M. Fake malaria and hidden parasites-the ambiguity of malaria. Anthropol Med 1998; 5: 42-61.

22 Kroeger A. Anthropological and socio-medical healthcare research in developing countries. Soc Sci Med 1983; 17: 147-161.

23 Amayunzu-Nyamongo M, Nyamongo L. Health seeking behaviour of mothers of under-five-year-old children in the slum communities of Nairobi, Kenya. Anthropol Med 2006; 13: 25-40.
24 Holzemeyer W L, Uys L R. Managing AIDS stigma. J Social Asp HIV/AIDS 2004; 1: 165-174.

25 Vecchiato N L. Sociocultural aspects of tuberculosis control in Ethiopia. Med Anthropol Q 1997; 11: 183-201.

26 Goesch J N, Schwarz N G, Decker M, et al. Socio-economic status is inversely related to bed net use in Gabon. Malar J 2008; 7: 60.

27 Schwartz N G, Gysels M, Pell C, et al. Reasons for non-adherence to vaccination at mother and child care clinics (MCCs) in Lambaréné, Gabon. Vaccine 2009; 27: 5371-5375.

28 World Health Organization. Traditional medicine programme. Resolution EB 63.R4. Geneva, Switzerland: WHO, 1979.
Contexte : Lambaréné, Gabon.

Objectifs : Décrire les perceptions de la tuberculose (TB) par les patients et déterminer les facteurs qui influent sur leur comportement de recours aux soins de santé afin d'y voir plus clair dans la prise en charge de la TB à germes multirésistants.

Schéma : On a mené l'observation des participants, des interviews semi-structurées approfondies ainsi que des discussions de groupe focalisé auprès de 30 patients TB, de 36 membres de leurs familles, de 11 pourvoyeurs de soins de santé et de 18 guérisseurs traditionnels/ spirituels. Le recrutement des patients a été lié à l'étude PanEpi et a eu lieu à I'Hôpital Albert Schweitzer, à l'Hôpital Général et au dispensaire du virus de l'immunodéficience humaine/TB.

Résultats : Les patients décrivent généralement la TB comme une maladie naturelle et/ou magique. La majorité des patients ont combiné le traitement hospitalier avec un traitement auto-administré par des herbes et par les soins traditionnels/spirituels. En dépit d'une disponibilité en principe gratuite du traitement TB, I'adhésion thérapeutique des patients a été problématique, ce qui a constitué un frein à la lutte effective contre la TB. La plupart des patients ont retardé ou abandonné leur traitement TB en raison de contraintes financières, de la stigmatisation, de l'ignorance concernant le traitement, de modifications du service des soins de santé ou de l'usage d'antibiotiques non prescrits. Occasionnellement, la situation s'est compliquée du fait de défauts d'approvisionnement des médicaments.

Conclusion: Il est urgent de combler le fossé entre les patients et I'hôpital en évitant les insuffisances de médicaments, en intensifiant une éducation pour la santé en matière de TB qui soit attentive aux facteurs culturels, en insérant les soins TB dans le contexte culturel et en renforçant la coopération entre les hôpitaux, les patients, les guérisseurs traditionnels et les collectivités.
Marco de referencia: Lambarené, Gabón.

Objetivos: Describir las percepciones que tienen los pacientes de la tuberculosis (TB) y determinar los factores que influyen en su comportamiento de búsqueda de atención médica, a fin de mejorar la comprensión del manejo de los casos de TB multidrogorresistente.

Métodos: Se llevaron a cabo observaciones de los participantes, entrevistas exhaustivas semiestructuradas y debates en grupos de opinión. Participaron en el estudio 30 pacientes tuberculosos, 36 familiares, 11 profesionales de salud y 18 curanderos tradicionales o líderes espirituales. Los pacientes que participaron formaban parte del estudio PanEpi y su inclusión tuvo lugar en el Hospital Albert Schweitzer, el Hospital General y el consultorio de atención de la TB y la infección por el virus de la inmunodeficiencia humana.

Resultados: En general, los pacientes describieron la TB como una enfermedad natural o mágica. La mayoría de pacientes asoció el tratamiento hospitalario con la automedicación y las prácticas curativas tradicionales o de los líderes espirituales. Pese a la disponibilidad de principio del tratamiento antituberculoso sin costo alguno, la aceptación del tratamiento y su cumplimiento fueron problemáticos, lo cual entorpece el control eficaz de la TB. La mayoría de los pacientes retrasó el comienzo del tratamiento o lo abandonó debido a las restricciones económicas, la estigmatización, la ignorancia sobre el tratamiento, el cambio del servicio de atención o al uso de antibióticos no recetados. En ocasiones la situación se complicó por causa del desabastecimiento de los medicamentos antituberculosos.

Conclusión: Existe una necesidad urgente de subsanar la brecha que existe entre los pacientes y el hospital, mediante la prevención de los desabastecimientos de medicamentos, la intensificación de una educación sanitaria en materia de TB que sea sensible a los aspectos culturales, la integración de la atención de la TB al contexto cultural y el refuerzo de la colaboración entre los hospitales, los pacientes, los curanderos y las comunidades.
Public Health Action (PHA) The voice for operational research. Published by The Union (www.theunion.org), PHA provides a platform to fulfil its mission, 'Health solutions for the poor'. PHA publishes high-quality scientific research that provides new knowledge to improve the accessibility, equity, quality and efficiency of health systems and services.
e-ISSN 2220-8372

Editor-in-Chief: Donald A Enarson, MD, Canada

Contact: pha@theunion.org

PHA website: http://www.theunion.org/index.php/en/journals/pha Article submission: http://mc.manuscriptcentral.com/pha 